\title{
Statistics of the Universities of Great Britain.*
}

WITH the current academic yoar has ended the five years for which the Parliamentary grant for universities and university colleges in Great Britain was fixed at its present figure, $£ 1,550,000$. Since 1919 the duty of advising the government of the day concerning the financial needs of these institutions has been discharged by the University Grants Committee, and this body has accordingly been engaged during the past twolve months in visiting them. In the light of the personal knowledge thus acquired and the various returns annually submitted to it, the Committee has prepared a review of the period 1923-24 to $1928-29$ and a report on prosent needs and problems. These documents have now been published, together with the customary statistical tables for the year 1928-29.

The total number of full-time students of both sexes last year was 44,309 . The total shown in the returns for $1923-24$ is 43,025 , but this includes 1742 students of a special type not representod in last year's total, namely, those aided to take univorsity courses under the Government scheme for the higher education of ex-Service men. Deducting those, the inerease in five years was 7 per cent. Taking mon students alone the incroase was 11 per cont, the number of women students showing a decrease from 12,962 to 12,899 , or from $31 \cdot 4$ per cent of the total of both sexes to $29 \cdot 1$. Dissection of the total enrolment figures according to the various subject groups discloses a marked contrast between an upward trend of enrolment in the arts faculties, including theology, fine art, law, music, commorce, economics, and education, and a downward trend in medicine (including dentistry) and tochnology (including engineering, applied chemistry, mining, metallurgy, architecture, etc.), and comparative stagnation in pure science and agriculture (including forestry, horticulture and dairy work) :

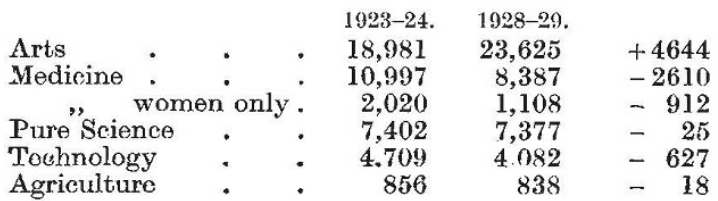

The 'swing-over' from medicine and technology to arts was widespread but was most pronounoed in Scotland, where the percentage of arts students rose from 44.2 to 59.3 (mon 31.4 to $47 \cdot 1$; women 70.7 to 83.9), and there were corrosponding declines in the proportions of students in other subject groups, and especially in medicine (men 38.1 to 29.3 ; women 17.9 to $7 \cdot 4$ ) and technology (men 17.8 to 10.5 ; women 0.5 to 0.4 ). It is accounted for thus : "Tho stationary position of the Pure Science group and the fall in the Technological group are no doubt due to the continued depression in many industries. The decreased number of students in the Medical group, which includes Dentistry as well as Medicine, seems to be the result of a reaction which followed the abnormally large entry of medical students just after the war." "The main reason for the growth in the Arts group is no doubt to be found in the attraction exercised, during a poriod of bad trade and restricted opportunities in other professions, by the securer and greatly improved prospects of the profession of teaching ; in Scotland the general tendency has been intensified by the official requirement that

* University Grants Committee. Report, including Returns from Universities and Cniversity Colleges in receipt of Treasury Grant, Academic Year 1928-29, Pp. 74. (London: H.M. Stationery Oflice, 1930.) 3s. 6a. net.

$$
\text { No. } 3170 \text {, VoL. 126] }
$$

only graduates can now normally bo admitted to the Provincial Centres for training as men teachers."

Each of these factors is mentioned in an article in the April number of The Universities Review on overcrowding in the German universities. There, however, the students of the technischenhochschulen, corresponding more or less to the technological faculties of the universities of Great Britain, form nearly twice as large a proportion of the total number of university students as in Great Britain, and scientific education is very widespread. Whatover its causes, the falling off in the numbers of students in the scientific departments of British universities cannot but excite misgivings on the part of all who believe in the importance for our future welfare of "integrating into the intellectual structure of society ", as J. B. S. Haldane puts it, "the scientific ideas which have furnished its material structure". In tho part of the report relating to careers open to graduates (see below) the Committee indicates reasons for anticipating an increase in the enrolments in technology and pure scienco.

In the following tables universities are arranged in order of the numbers of their full-time students in 1928-29, first in all facultios and then (omitting many of the smaller enrolments) in the above-named subject groups severally. It will be seen that London heads the list in every case except arts and agriculture, in which, respectively, Oxford and Reading rank first, that Cambridge comes second in every case except medicine, and that Glasgow is third in every case except agriculture. The increase $(+)$ or decrease ( - ), in comparison with the corresponding figure for $1923-24$ is given in brackets :

\begin{tabular}{|c|c|c|}
\hline \multicolumn{3}{|c|}{ All Faculties. } \\
\hline *London & 9141 & $(+186)$ \\
\hline Cambridge & 5653 & $\begin{array}{r}100 \\
(+676)\end{array}$ \\
\hline$\dagger$ Glasgow & 5329 & $(\div 562)$ \\
\hline Oxford & 4559 & $(+396)$ \\
\hline Edinburgh & 3616 & $(+47)$ \\
\hline$¥$ Wales. & 2664 & 1) \\
\hline sManchested & 2314 & $(+52)$ \\
\hline Liverpool & 1560 & $(-239)$ \\
\hline 'Durham & 1431 & $(\div 70)$ \\
\hline Leeds. & 1385 & $(-90)$ \\
\hline Birmingham & 1362 & $(-143)$ \\
\hline Aberdeen & 1325 & $(-118)$ \\
\hline ขBristol & 859 & $(-88)$ \\
\hline Sheffield & 690 & \\
\hline St. Andrews & 677 & $(-6)$ \\
\hline Reading & 615 & $(1-37)$ \\
\hline
\end{tabular}

* 23 institutions: among them 2 medical schools, with enrolment 151 , not represented in returns of 1923-24.

$t$ Including Royal Technical College, Glasgow.

$\ddagger$ Cniversity Colleges at Aberystwyth, Bangor, Cardiff, and Swansea.

$\$$ Including Manchester College of Technology.

I: Armstrong Coll., Newcastleupon-Tyne, and Durham Colleges, including college of Medieine. Including Merchant Ven. turers' College.

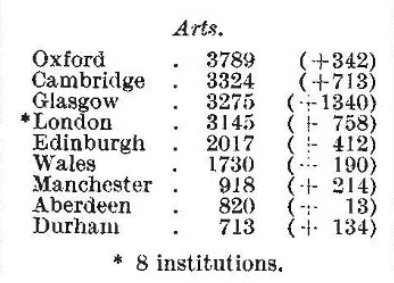

\begin{tabular}{|c|c|c|}
\hline \multicolumn{3}{|c|}{ All other Faculties } \\
\hline ondon & . 5996 & $(-572)$ \\
\hline ridge & & $(-37)$ \\
\hline & 2054 & 778 \\
\hline argh & 1599 & 365 \\
\hline hester & . 1396 & $162)$ \\
\hline & & \\
\hline pool & 921 & \\
\hline & 823 & \\
\hline & 770 & \\
\hline ingham & 729 & \\
\hline tham & . $\quad 718$ & \\
\hline \multicolumn{3}{|c|}{ Medicine. } \\
\hline adon . & . 3373 & -611 \\
\hline burgh & 1105 & \\
\hline$w$ & 886 & 41 \\
\hline ester & 412 & -1 \\
\hline lbridge & 386 & \\
\hline rpool & . $\quad 379$ & 300 \\
\hline eds & . $\quad 332$ & \\
\hline \multicolumn{3}{|c|}{ Pure Science. } \\
\hline ndon. & . 1604 & $(-1$. \\
\hline rilge & 1184 & \\
\hline & 588 & 1.125 \\
\hline & 570 & -111 \\
\hline iester & 560 & +46 \\
\hline d. & 522 & -131 \\
\hline & 297 & $(+67$ \\
\hline & 277 & $(-4$ \\
\hline rpool & 275 & -11 \\
\hline mingham & 238 & \\
\hline nburgh & - 220 & - \\
\hline \multicolumn{3}{|c|}{ Technology. } \\
\hline ndon. & . 1019 & $(+3$ \\
\hline mbridge & 581 & \\
\hline & 554 & -469 \\
\hline icheste & 424 & \\
\hline rpool & 267 & \\
\hline mingham & 199 & \\
\hline eds & 173 & -84 \\
\hline linburgh & 168 & 46 \\
\hline field & 167 & \\
\hline \multicolumn{3}{|c|}{ Agriculture. } \\
\hline ading & 181 & $(\because 46)$ \\
\hline ridge & 178 & \\
\hline finourgn & 106 & \\
\hline ford : & 105 & $(-2$ \\
\hline erdeen & $\begin{array}{l}88 \\
78\end{array}$ & $(+5$ \\
\hline
\end{tabular}


The number of full-time advanced students (as distinguished from those pursuing courses for first degrees or diplomas) shown in the returns for 1928-29 is 2082 , including 374 women. The following table compares their distribution over the various subject groups with the distribution of the total number of full-timo students :

\begin{tabular}{|c|c|c|c|c|c|c|}
\hline Arts & • & & \multicolumn{2}{|c|}{ All students. } & \multicolumn{2}{|c|}{ Advanced. } \\
\hline Medicine & . & $\cdot$ & $18 \cdot 9$ & , & $4 \cdot 8$ & , \\
\hline Pure Scienco & . & . & $16 \cdot 7$ & , & $42 \cdot 6$ &, \\
\hline Technology & . & . & $9 \cdot 2$ & , & $11 \cdot 4$ & , \\
\hline Agriculture & . & . & $1 \cdot 9$ & , & $2 \cdot 1$ & , \\
\hline
\end{tabular}

Two-thirds of the total number of these advanced students wore at work in London $(696$, including 246 at University Collego and 207 at Imperial College), Cambridge (378), Oxford (185), and Manchester (153). In the Scottish universities there were 182, and in the Welsh 97. (of the individual subjects by far the most popular among advanced students are chomistry (453) and physics (185).

The universities of Great Britain are drawing students from other countries in increasing numbers : so much so that more than half the total increase during the quinquennium in the number of full-time students is attributable to this source. Those from other parts of the British Empire numbered 2809 in 1928-29, being 14 per cent more than in 1923-24, whilst those from foreign countries numbered 1581, showing an increase of 26 per cent.

The financial resources of the universities of Great 13ritain are exhibited in the returns for 1928-29 in some detail. The incomes amounted in the aggregate to $£ 5,174,510$, and were derived from : $(a)$ Parliamentary grants, 36 per cent; (b) fees, 31 per cent; (c) endowments, 14 per cent; (d) grants from local authorities, 10 per cent; and $(e)$ other sources, 9 per cent. Capital benefactions received from other than Government sources in the course of the past five years amounted to more than $£ 5,550,000$, in which total are included gifts by corporations and individuals in the United States of America amounting to $£ 1,700,000$, nearly ono-third of the total. Excluding these American contributions, the benefactions in five years amounted to less than one-sixth of the amount received as gifts and bequests in one year by universitios and colleges in the United States, and about one-fourth of the amount received in one year by sixtcen of the most favoured of them. The aggregate income is about half that of the univorsities and colleges of the State of New York. Sources of American university incomes are : $(a)$ United States Government grants, 5 per cent ; $(b)$ fees, 32 per cont ; (c) endowments, 16 per cont; (d) grants from State or city governments, 26 per cent ; $(e)$ other sources, 23 per cent.

Since figures for Oxford and Cambridgo wore not available at the beginning of the quinquennium on a sufficiently comparable basis to be included in the University Grants Committoe's standard tables of financial statistics, the Committee's comparative statements of income and expenditure in 1923-24 and 1928-29 leave those two universities out of the reckoning. The comparison shows a growth of total income from $£ 3,592,936$ to $£ 4,210,710$, approximately 17 per cent. Rather more than half of the increase is under the head of Parliamentary grants. Income from endowment shows an increase of $£ 72,822$ (18 per cent), from donations and subscriptions $£ 23,989$ (26 per cont), from local education authorities' grants $£ 92,926$ ( 22 per cent), and from fees $£ 44,267$ (4 per cent). The proportion of Parliamentary grants to total income rose from $35 \cdot 4$ to $37 \cdot 8$ per cent, and that of fees to total income fell from $33 \cdot 7$ to $29 \cdot 8$ per cent. The only institutions deriving more than half of their income from Parliamentary grants are three of the London colleges, two Welsh colleges and Reading. Oxford and Cambridge get, respectively, 30 and 25.6 per cent of their incomes from this source. The Committee concludes an examination of the question of the increasing dependence of universitios on State aid with the observation that the large increase in the grants given by the State five years ago has served to stimulate rather than to discourage the generosity of the other bodies and individuals to whom the universities have to look for support.

That depondenco is about to be furthor increased by the raising of the amount of the annual Treasury subvention from $£ 1,550,000$ to $£ 1,800,000$. The report stresses, in this connexion, the fundamental importance of the teaching staff and the library and expresses the hope that one of the first uses to which the universitios will put any inerease they may obtain in their annual incornes will be to improvo the lot of teachers of the senior lecturer class, many of whom find thomselves in a serious plight. In discussing the position and prospects of the junior staff, the Committee directs attention to the barriers which stand in the way of their obtaining posts in secondary schools. These barriers have arisen through the operation of the new salary scales for teachers in schools and, in Scotland, the requirement that, whatever their previous experience, all applicants for such posts must have had a course of professional training for school work. This is, the Committeo thinks, unfortunate, as the universities and schools both stand to gain by such exchanges.

In the part of the report relating to the careers open to graduates we find: "The need for a much more extensive application of scientific research to industrial practice is becoming more clearly realised every day, and the scientific departments of the universities are the obvious training grounds for men and women qualified either to undertake work on the fundamental problems, which are the field of the Industrial Research Associations established with State assistance, or to devote themselves, in the service of individual firms, to the improvement of particular industrial processes. . . Some years ago it was common knowledge that the 'market' for chemists was seriously overstocked, and that many men with first-rate qualifications in Pure Chemistry were unable to obtain suitable employment, but we gathor that the market has of late greatly improved, under the enlightened influence of the great combine over which Lord Melchett presides, and that though the output of students trained in Pure Chemistry continues to be, perhaps disproportionately, large, it is now being successfully absorbed. ... There is evidence of an increasing range of demand for men who have had a good training in Physies, Geology, Biology, and such applications of Chemistry as Chemical Engineering or Fuel Technology."

The domand for university graduates is, moreover, we are told, extending rapidly to the administrative side of industry and of business generally. While it has hitherto been rare in Great Britain, though common in Germany, to give to men of high technical qualifications a place on the directorate of an industrial firm, many of the large industrial organisations are coming to look more and more to the universities for men of good general education and balanced character for the responsible administrative work which the vast range of their operations now involves, and even the smaller concerns seem more willing than they were to have recourse to the same recruiting ground.

No. 3170, VoL. 126] 